\title{
Learning Styles and the Role of Technology in Second Language Learning
}

\author{
Fauzan Atsari \\ Faculty of Humanities \\ University of Indonesia \\ Depok, Indonesia \\ fauzan.atsari@ui.ac.id
}

\begin{abstract}
Language learning is an aspect of life that is affected by technology. As we realize, for example, a smartphone can function as reading text and dictionary. However, since every learner has distinct learning style, it is important for teacher to consider the way technological tools are used in teaching. The appropriate use of technological tools is potential to encourage learning activities. This literature study research is aimed to review studies that have already been done in field of learning styles and the role of technology in second language (L2) teaching and learning. The researcher reviewed previous researches in order to associate research findings in those fields to draw a general conclusion. As a result, not all findings showed and agreed that learning style affect learners' achievement significantly. Regardless of the data showing disagreement, it is still necessary to pay attention to learners' learning style to be adjusted to selection and use of technology in the classroom.
\end{abstract}

Keywords: learning styles, technology

\section{INTRODUCTION}

Nowadays, technology is being developed rapidly and affecting various aspects in human life. By the development of technology, various tools have been made to ease our daily activities, including teaching and learning. Decades ago, people should go to a bookstore for getting literature they were looking for. They even could not ask anyone directly when getting problem while learning something. This time, people can look for, order, and purchase any book they want at once even without moving from chair in their office. They can also ask other people directly without making appointment when facing difficulty in the learning process.

Nevertheless, despite the many positive effects brought by the products of technology advancements, the potential for the emergence of negative impacts in not immediately eliminated. If not be used properly, the tools resulting from technology developments can actually worsen the teaching and learning process. For example, lately, there have been so many researches integrating game and learning. Although the results show that game can be used as a tool that supports learning process, since not all learners like to learn by playing game, the method cannot be applied to all learners as a whole.

According to Gilakjani [1], generally, a person's learning style is classified into three categoriess. There are people who like to learn by watching, namely visual learners. There are also those who like to learn by listening. They are auditory learners. At the same time, students belonging to the kinesthetic category are those who feel more suitable to learn by involving themselves directly in what they are learning.

The differences in learning styles is believed to influence the level of acquisition of a learner when learning something. So far, there have been various studies proved that learners tend to achieve maximum results when learning something in a way that suits their learning style. This also applies to language learning. Therefore, it is proper for teachers to take into account the differences between each learner when teaching them. In addition, the use of tools that support learning process can also be arranged to suit students' learning styles so as to create a comfortable and enjoyable learning process.

It is undeniable that the role of technology nowadays is so significant for the process of teaching and learning, both inside and outside the classroom. In addition to helping teacher teach, technology can also be used to create better learning conditions and increase the acquisition of learners [2], [3], [4]. Using technological tools to support language teaching and learning has proven to be beneficial for both teachers and learners. The use of technology also provides positive impact on learning language [5].

The use of technology for the purpose of teaching second language is not without reason. A number of studies have been conducted to determine the purpose of teachers using information and communication technology (ICT) to teach languages. The first is to construct students' interest in learning [6]. Students' interest in learning can increase when they have the opportunity to choose their own technology products that they want to use as a means of learning languages. Products of technology are very diverse. Hence, by letting students choose their own tools and ways of learning according to their preferences, the possibility of them being more motivated becomes higher. For example, students who like to play games and are not really like reading books can choose to learn English through game applications that simultaneously teach English such as ubiquitous games (7). The next is to provide opportunities for students to communicate. By using technological equipment, students who are initially quite in the classroom can be brave enough to interact or simply ask questions and express opinions. This also increases the level of interaction between teachers and 
students. The next purpose of using technology for teaching language is becausr it is considered effective. In other words, using technology provides flexibility in learning process. By utilizing ICT products, learning can not only be held in the classroom according to the learning schedule but also outside the classroom based on the time agreed upon by the teacher and students [3]. Moreover, ICT can reflect more authentic context that describes the use of language in real life. This can make students feel the language they learnt is applicable [8].

Despite of providing many advantages over traditional language teaching and learning, the use of technology still leaves some lacks that should be considered by teachers before applying it to the teaching process. The first shortcoming is in the teachers' lack of preparation in using technological tools that can actually hamper the learning process. There are many factors that make teachers not ready to use ICT. Among the factors are their comfort in traditional teaching methods that make them not willing to bother studying how to use technology properly for teaching, difficulty that prevents them from using technology, and their attitudes and cognition towards technology [9]. Regardless of various factors that cause teacher to be unprepared to use ICT products, teacher trainers must really ensure that language teachers are technologically literate in order to be able to carry out technology-based learning optimally. The second deficiency is inadequate tools that support language learning process. Sometimes, although teachers are ready to use technology for teaching, available technological tools are damaged so the teacher has to go back to using traditional ways to teach language. For example, when a projector displays a yellowish color or takes a long time to set, teachers who do not have many choices must go back to using the whiteboard or any traditional tool to teach. In addition to these two shortfalls, attitudes of teachers and learners who are still lacking in technology also hamper the teaching and learning process with technological tools [8].

Furthermore, the role of teachers in learning language using ICT is no longer merely using technology products as assistive device for conveying learning material. More than that, language teachers should be able to create interactive teaching and learning conditions so that students can stay motivated to learn the language [10]. It is important to note considering the magnitude of the influence of motivation on student learning achievement [11]. Therefore, teachers must improve their self-efficiency in using technology. They must also understand the interplay of technology, language pedagogy, and content [12]. Successful implementation of technology-based pedagogy in the classroom is more likely to take place when teachers see technology as a means to an end, rather than the goal itself, and when they see a close relationship between technology and curriculum [13].

In fact, the positive influence of the use of technology in language teaching have been proven by previous researches. According to research conducted by Mafuraga and Moremi [10], the majority of teachers have realized the importance of using technology media in the process of teaching English. The teachers, he added, must know how to use ICT to achieve teaching goals so that the use of ICT is not only as teaching aids that do not provide meaningful value. Basically, ICT is dynamic and interactive so that it can meet every students needs.

An example of the application of technology in second language teaching and learning is the use of backchannel to collaboratively build meaning with texts through discussion. Backchannel is a real-time online conversations taking place simultaneously with spoken discussion. This research was conducted by Seglem and Haling [14] to find out how undergraduate pre-service teachers make use of backchannels to talk about class-assigned tests. One of the findings of this study is that participants in the backchannel group can make meaning through the interaction they do. In addition, the use of backchannel also allows students to ask questions and respond directly to their peers without having to wait for the teacher to give them an explanation. This condition makes both students and teachers as source of knowledge. The prominent distinction that can be seen in the use of backchannel, compared to traditional classroom teaching, is student participation. In traditional classes, active and vocal students tend to stand out while those who are quiet almost never seem to ask questions or give opinions during the learning process. By using backchannel, all students get the opportunity to increase their participation.

Not only is it directly useful for increasing acquisition in language learning, ICT have also been proven to have a positive impact on the development of language teaching and learning from various aspects such as the motivation sector [14] and feedback [15]. However, to involve the role of technology in the learning process, teachers must really consider the benefits and risks of it. In addition, training is also important to be held so that teachers and students have good knowledge about technology and its use.

Research in pedagogy has proven that humans learn in different manners, rates, and under different circumstances. Therefore, it is necessary for teachers to pay attention to the differences between students in order to maximize the delivery of teaching materials. The variety of styles that become a person's tendency to learn is often referred to as learning style. It is considered as a factor that directly affect students' learning processes [16]. The existence of learning styles needs to be considered by teachers in teaching language because, in addition to using diverse teaching method, teachers should also be able to teach by making the classroom environment as interactive and interesting as possible. Furthermore, each learning process carried out in accordance with students' learning styles is proven to make the learning process more effective and achieve maximum results [17], [18]. Otherwise, since every student with a certain learning style has strengths and weaknesses in dealing with certain circumstances, teaching and learning process that is not suitable with the students' learning styles has the potential to reduce students' motivation [19]. Therefore, teacher should adjust their teaching style so that it is more congruent with a given student's or class of students' learning styles. 
to what the teacher says. Auditory learners can digest meanings conveyed through tone, pitch (high and low), speed of speech, and other auditory matters. Written information sometimes has minimal meaning for auditory learners. However, they can memorize more quickly by reading texts aloud or listening to someone who reads it [20]. The following are characteristics of auditory learners.

- Very talkative

- Prefer oral directions than written ones

- Enjoy listening to music or oral lessons

- Tend to lose consentration easily when in noisy condition

- $\quad$ Like to read by moving lips

Unlike teaching visual students, teachers do not really need visual teaching equipment to teach those with auditory learning style. As mentioned, auditory students are considered to enjoy lectures without much visual input. However, it is better for teachers to increase the activities that give students space to take oral interactions such as conversations, roleplays, and debate. The following are some recommendations to engage auditory students.

- Give clear verbal instructions

- Give tasks that make students discuss each other

- Ask questions that make students respond verbally

- Use audio tools such as beats, rhymes, and songs to support the delivery of information

- $\quad$ Provide verbal summary of lesson at the end of class or presentation

To teach visual type students, it is good for the teacher to use or at least involve visual devices such as picture and writing. Paying attention to what will be written on the board or be presented on presentation slides is important because visual learners will really focus on it. Furthermore, the use of media that allow teachers to write teaching material in various colors is highly recommended. The following are some recommendations to engage visual students.

- Write out the directions

- Demonstrate tasks physically

- Use color codes for organizing information and keep the color codes consistent

- Use visual tools such as pictures, diagrams, and charts

- Provide note or written summary of lesson at the end of class or presentation

\section{B. Auditory Learning Style}

The second type of learner is auditory learner. Learners with this type rely on their ears, as a sense of hearing, to achieve successful learning. Hence, teacher should pay attention to the students' hearing aids and ensure that they hear every instruction clearly. Learners with auditory learning style can learn faster by using verbal discussion and listening

\section{Kinesthetic Learning Style}

The third type of learner is kinesthetic learner. Those who have kinesthetic learning style tend to learn by involving themselves physically to what they are learning. They like to move, touch, and practice what they learn directly. It is considered hard by kinesthetic learners to just sit for hours since their desire to do activities and exploration is very strong. Some characteristics of kinesthetic learner are as follow.

- Like moving a lot

- Like to participate in learning

- Like to do things directly than just read about them

- Using gestures while talking

- Like to touch objects

How to teach kinesthetic students can be considered different from the way to teach visual and auditory students. Visual students can read comfortably for a long time and auditory students can keep paying attention to the teacher talking without getting bored quickly. Yet, kinesthetic students enjoy learning activity with a lot of movement and the use of real and touchable objects. Moreover, they will feel 
uncomfortable to sit for very long time. As a consequence, teachers teaching kinesthetic students should provide sufficient opportunity to break and move around the classroom. Some of the recommended ways to teach kinesthetic students are as follows.

- Present learning materials in an interactive way that require students to be active

- Teach outdoors if possible

- Provide hands-on learning tools

- Let students answer question on whiteboard

- Give the opportunity to break and move regularly

So far, much research on the correlation between learning styles and achievement in learning has been done. Some researchers used an experimental and control groups to compare the learning progress achieved by students taught by considering learning styles and not [21], [22]. The results show that teaching and learning activites adapted to learning styles has positive effect on students achievement. On the other side, there are researchers who claim that learning strategies does not have significant impact on student learning achievement but the environment. The appropriate use of teaching and learning tools is more important than type of media utilized [23].

\section{CONCLUSION}

A teacher cannot teach a class just by applying a single teaching style and hope that it will be effective for the students as a whole except if the class has been designed to be homogeneous according to the student learning styles. However, it is almost impossible since the division of students will be very complicated. Therefore, teachers should be aware to the differences in the learning styles of the students and try to match the teaching and learning style so that the learning environment become as effective as possible for all students in the classroom or place of teaching and learning [17].

After analyzing the results of previous researches related to the use of ICT for language teaching and the role of learning styles in language learning, the author has several recommendations that can be applied by teachers to teach or be further investigated by researchers. The way is by using technological tools that can integrate the delivery of material visually, auditorily, and kinesthetically. The reason for the need for instrument like this in teaching is because teachers are most likely unable to teach each group of students with a different learning style one by one. Actually, there is still possibility for teachers to divide time to explain one material visually for several minutes to a group of students with visual learning style and then continue auditorily and kinesthetically in turn. However, this method will be very time consuming and make some learners not pay attention to the teacher. For that reason, some technology products and how to use them for teaching are recommended.

The first recommended technological tool is presentation slides that can integrate lesson delivery visually, auditorily, and kinesthetically in the classroom. It can support teachers to present material with images, video, and sound. By using presentation slides, teacher can display pictures of things or activities with written and verbal description. At the same time, the teacher can also display games or exercises that make kinesthetic students go forward to answer questions or demonstrate something. Still, this does not mean that the teacher no longer needs to give instructions to students. The teacher should continue to stimulate students so that they remain enthusiastic and can be helped when getting into trouble.

Another recommendation is to use video call applications to carry out learning outside the classroom. Through video conferencing, visual students can pay attention to the teacher talking on the device screen. On the other hand, auditory students who only want to listen the voice can also benefit from it. For kinesthetic students, because it is done outside the classroom, they can freely demonstrate or practice what is instructed by the teacher via video conference. Nonetheless, further studies still need to be held regarding the effectiveness of this method since video conference participants in most devices and applications are yet still limited for small numbers. Further research is also expected to find more efficient ways in using presentation slides or even other technological tools that can be more effectively utilized.

\section{REFERENCES}

[1] A. P. Gilakjani, "Visual, Aauditory, kinaesthetic styles and their impacts on English language teaching,” J. Stud. Edu., vol.2, pp. 104-113, 2012.

[2] M. J. Riasati, N. Allahyar, K. Eng Tan, “Technology in language education: benefits and barriers," J. Edu. Pract., vol.3, pp. 25-31, 2012.

[3] S.D. Shyamlee, "Use of technology in English language teaching and learning: an analysis," Int. Conf. Lang., Med., and Cult., vol.33, pp. 150$156,2012$.

[4] M. R. Ahmadi, "The use of technology in English language learning: a literature review,” Int. J. Res. Eng. Edu., vol.3, pp. 115-125, 2018.

[5] M. Altun, "The integration of technology into foreign language teaching," J. New Trends Edu. and Their Impl., vol.6, pp. 22-27, 2015.

[6] W. V. Wu, L. L. Yen, and M. Marek, "Using online EFL interaction to increase confidence, motivation, and ability," Edu. Tech. Soc., vol.14, pp.118-129, 2011

[7] T. -Y. Liu and Y. -L. Chu, "Using ubiquitous games in an English listening and speaking course: impact on learning outcomes and motivation," Comp. Edu., vol. 55, pp. 630-643, 2010.

[8] N. Serostanova, "Integrating information and communication technologies in the process of foreign language teachind and learning," J. Edu. Cult. and Soc., vol.1, 187-197, 2014.

[9] N. B. Razak, H. Alakrash, and Y. Sahboun, "English language teachers' readiness for the application of technology towards fourth industrial revolution demands," Asia-Pacific J. Inf. Tec. Mul., vol.7, pp. 89-98, 2018.

[10] M. Mafuraga and M. Moremi, "Integrating information and communication technology in English language teaching: a case study of selected junior secondary schools in Botswana," Int. J. Edu, and Dev. Using Info. Com. Tech., vol.13, 142-152, 2017.

[11] F. H. Al Othman and K. M. Shuqair, "The impact of motivation on English language learning in the Gulf states," Int. J. High. Edu., vol.2, pp.123-130, 2013.

[12] K. J. Graziano, “ Preservice teachers' comfort levels with technology in an online standalone educational technology course," J. Teach. and Learn. with Tech., vol.7, pp. 70-86, 2018.

[13] Y. Zhao, K. Pugh, S. Sheldon, and J. L. Byers, "Conditions for classroom technology innovations," Teach. Col. Rec., vol.104, pp. 482 515, 2002. 
[19] P. Pallapu, "Effects of visual and verbal learning styles on learning," Inst. Learn. Style J., vol.1, pp.34-39, 2007.

[14] M. Ebrahimzadeh and S. Alavi, "The effect of digital video games on EFL students' language learning motivation,” Teach. Eng. Tech., vol.17, pp. 87, 2019.

[15] M. Hast and C. Healy, "It's like fifty-fifty: using the student voice towards enhancing undergraduates' engagement with online feedback provision," J. Teach. Learn. Tech., vol.7, pp.139-151, 2018.

[16] F. Vizashfar and C. Torabizadeh, "The effect of teaching based on dominant learning style on nursing students' academic achievement," Nur. Edu. Prac., vol.28, pp.103-108, 2018.

[17] A. P. Gilakjani and S. M. Ahmadi, "The effect of visual, auditory, and kinaesthetic learning styles on language teaching," Int. Conf. Soc. Sci. Hum., vol.5, pp.469-472, 2011.

[18] A. P. Gilakjani, "Visual, auditory, kinaesthetic learning styles and their impacts on English language teaching,” J. Stud. Eng., vol.2, pp.104-113, 2012 .

[20] R. L. Oxford and M. Ehrman, "Second language research on individual differences," Ann. Rev. App. Ling., vol.13, pp. 188-205, 1993.

[21] L. Litta, H. Atmowardoyo, and K.Salija, "The effects of visual auditory kinesthetic learning style as teachnique in improving students' writing ability," ELT Worldwide, vol.2, pp. 62-76, 2015.

[22] M. T. A. N. Hardiana and P. Suyata, "The effectiveness of VAK (visual, auditory, kinesthetic) model in learning summary writing," Int. J. Res. Rev., vol.5, pp. 43-49, 2018.

[23] M. Yilmaz-Soylu and B. Akkoyunlu, "The effect of learning styles on achievement in different learning environments," TOJET, vol.8, pp. 4350, 2009. 